\begin{tabular}{|ccc}
\hline Sournals & $\begin{array}{c}\text { INTERNATIONAL JOURNAL OF } \\
\text { ORGANIZATIONAL LEADERSHIP }\end{array}$ & $\begin{array}{c}\text { INDUSTRIAL } \\
\text { MANAGEMENT } \\
\text { INSTITUTE }\end{array}$ \\
\hline \hline
\end{tabular}

\title{
A research on levels of organizational learning in educational institutions
}

\author{
Recep Kaçmaz ${ }^{1}$, Celaleddin Serinkan ${ }^{2 *}$ \\ ${ }^{1}$ Asst. Assoc. PhD, Mevlana University, Department of Management, Konya, Turkey \\ ${ }^{2}$ Assoc. PhD, Pamukkale University, Department of Management, Turkey \\ (Visiting Prof., Kırg1z Turkish Manas University, Bishkek, Kyrgyzistan)
}

\begin{tabular}{l}
\hline \\
Keywords: \\
Public Institutions, Private \\
Educational Institutions, \\
Learning, Individual \\
Learning \\
\hline Received \\
17 February 2016 \\
Received in revised form \\
13 June 2016 \\
Accepted \\
22 June 2016 \\
\hline
\end{tabular}

Correspondence:

cserinkan@hotmail.com

\begin{abstract}
Nowadays changes and developments are being experienced in the roles of educational institutions. Educational institutions should respond against these changes and developments by adopting the approach of "teaching" as well as the concept of "learning" and by making organizational learning subject an integral part of their corporate culture. The purpose of this study is to compare the levels of organizational learning in public and private educational institutions, if any, to focus on the causes by analyzing differences. Survey sample is consisted of 916 administrators and teachers working in public and private educational institutions in Denizli province, in Turkey. The research sample of 525 persons was formed by stratified sampling technique. Survey methodology was selected as data collection method and 5-point Likert-type statements were used on scales. To make a comparison in public and private educational institutions, the data obtained were subjected to t-test and mean values were calculated for each learning level. As a result, the learning at all levels in both the public and private educational institution has not proved at "high level". However, in the study it has been found that learning at all levels in private educational institutions was relatively higher than the public institutions.
\end{abstract}

(C)AIMI Journals

The educational institutions have entailed permanent learning in order to become dynamic, be compatible with the constantly changing environment, and compete with them. In other words, institutions have to be able to respond to the changes and developments which happen in their neighbourhood with new learning. This situation puts forward the importance of organizational learning for the educational institutions. Owing to the fact that competition among the organizations, which happens all around the world, interior and exterior environmental 
conditions affect even the organizations which are designed perfectly, it shouldn't be considered that educational institutions stay out of this change and development.

Organizational learning should be started with individual who is the most basic of public institutions and individual learning. In the event that individuals head for a common goal by interpreting what they have learnt and the experience they have gained, they will exhibit team learning. By the way of learning results, which individuals and teams have reached by learning together, being reflected on all behaviours of the institutions, organizational learning will occur. In addition to communion and dialogue, top management should contribute to individual and team learning's being able to change into organizational learning. Organizational learning will occur by means of public executives' creating environments which enable learning and the data's gained being spread to all institutions through true ways.

In organizations, organizational learning which points out to the process of obtaining data that has become basic factor of production, adding various data and changing data has become compulsory for the organizations to exist (Mirzaei Daryani, Sattari Ardabili, \& Amini, 2014; Koç, 2009). Organizational learning will contribute greatly to the institutions catching the fast changes happening nowadays. Organizations that can interiorise learning culture as an indispensible behaviour, can develop themselves constantly by means of their workers' and teams' learning and can succeed in updating themselves against change by performing elastic behaviour that will help them to achieve their goals easily and fast.

The subject of organizational learning should be basic concept of the schools being as educational institutions of the today's information society. Moreover, schools should give importance to the organizational learning much more than the other sectors. While the missions of the organizations in different sectors are to produce a product or service, the missions of the schools in education sector is to give educational service directly. Continuous learning in school environment has occurred through students', teachers', and school managers' individual and community learning (community work, educational meeting) and learning across the school.

The purpose of this study is to analyze the relations between the levels of organizational learning, to determine on which levels organizational learning has happened and to confirm whether there is difference between public and private institutions. In other words, the aim of this study is to indicate on which stages organizational learning has occurred in educational institutions and to determine whether there are differences between public and private educational institutions or not. In the wake of the study that was conducted, statically significant differences have been detected. In all learning levels having taken part in the research, it has been determined that the marks of private educational institutions are higher.

\section{The Literature Review}

\section{Learning Concept to Organizational Prospective}

Learning is a process that ends up with a permanent change in behaviours, which arises from experience and repetition (Bacanl1, 2002; Morris, 2002). While in the beginning, learning term was an issue on which psychologists and educators did research and was evaluated on individual learning level, later on, it was examined by scientists who worked with business world like economists and managers and the subject was generally looked into from the 
perspective of grounds on behavioural change of individuals in working-life (Aydoğan, Orhan, Naldöken, Beylik, \& Aksay, 2011).

Organizational learning term was first developed by Cyert and March and these academicians defined organizational learning as the process of organization's adoption to the environment and of organization's problem solving and strengthening the capacity of working (Öncül, 1999). Organizational learning term emerged in the middle of 1970s and it was defined by Argyris as the process in which errors are determined and corrected (Argyris \& Schon, 1996). Organizational learning is a more complicated event which occurs through individuals' and organizations transferring what they have learnt into their job environment. Learning of an organization should be dealt as the process ensuring to create environments to produce new data and to use the data in new products and new services by following the latest technological developments by regarding the data obtained as an experiment and to provide the data to be used for productivity of the organizations (Doğan, 2010).

When evaluated within the organizational point, learning is the process of developing and improving data and qualifications (Erçetin, 2001). The organizations that have learnt learning are organizations which have the ability to produce knowledge, obtain, transfer, and arrange their behaviours in the form of being able to project new data and opinion. The organizations that have learnt learning are able to manage learning process actively not as a result of coincidence but to ensure that it happens by design (Y1ldırım, 2006).

\section{Organizational Learning Levels}

Organizational learning levels are dealt in three levels that are individual learning, team learning, and organizational learning. Marsick and Watkins (1999) and Vera and Crossan (2004) also added community learning as the fourth level.

Individual Learning: Learning of individual in institutions is possible through comprehending individuals' levels of actual learning and concept learning, their experience, the role of memory, their intellectual patterns, and their understanding patterns of the environment (Şahinkesen, 2010). Individual's learning ability depends on intelligence, age, and general stimulation state. Learning ability increases until young adulthood, then it remains stable for a while; it decreases in median age and in advance ages for a while. Learning ability increases until young adulthood, then it remains stable for a while; it decreases in median age and in advance ages for a while (Şimşek, Akemici, \& Çelik, 1998).

In study related to individual learning, it has been determined that the workers are inclined to the subjects which are learning from their mistakes, following the sectoral and professional improvements, and benefiting from successful people's knowledge and experience. However, the workers are less inclined to the subjects which are interpersonal dialogue or relates to sharing their experience with others; the reason is that workers use their knowledge as an individual means of competition (Avc1, Kılınç, \& Okumuş, 2010). In another study, in the subject of the individual learning the argument that "the workers have learnt by helping each other" has the highest average while the argument stating that "workers are rewarded because they have learnt" has the lowest average (Erigüç \& Balçık, 2007). 
Team Level Learning: Team learning which functions as a bridge in transferring what have been learnt in individual level into organizational level grounds on learning of members who compromise the group by establishing dialogue with each other. Team learning gives the chance to its members to learn from their workmate's experience and proficiency by studying together, by sharing the data, and by watching them (Marsick \& Watkins, 1999). Learning that occurs in teams is much more than the total data individuals have one by one. Team learning requires sharing and being integrated with one another. In teams there is not good communication, confidence, and sharing environment; in addition, individual data cannot be learnt by the other members in the team. Certain parts of the data disappear in the course of the mutual transfer or are not learnt by other members (Lucas, 1999; Nikooravesh, Parpoochi, \& Mohammad Davoudi, 2016).

In the study on fifteen teams and one hundred and eleven team members who make production for defence industry in Turkey, communication, using the resources, the goals of performance and of competence are the five factors that constitute effective teamwork (Zehir \& Özşahin, 2008). Team leader also play important role in team's working effectively (İnce, Bedük, \& Aydoğan, 2004).

In the study which was performed about team learning, the argument that "teamwork is supported in our management" has the highest average while the argument that "all the workers in our management help each other in development" has the lowest average (Avc1 et al., 2010). In another study, the argument that "work groups have been able to discuss various ideas through collecting data or as a consequence of group discussions" has the highest average while the argument that "work groups have been rewarded as a result of their success" has the lowest average (Erigüç \& Balçık, 2007).

Learning in Organizational Level: Organizational learning is the process in which organizations can develop their learning ability and experience. In industrial societies, learning through team work has substituted for learning through working individually (Aytaç, 2000). Organizational learning has required behavioural change including relationships to have practice and difference constituted, gained, and transmitted (Karadağ, 2002).

In the research that was done about the subject of learning at organizational level, factors about organizational learning have been ranged from the top to the bottom: continuous improvement, open-mindedness, attitude of the management, using initiative, and education and development (Avc1 et al., 2010). In other research, the argument that "learning lessons are given to all workers" has the highest average, the argument that "a system testing the difference between current performance and expected performance" has the lowest average (Erigüç \& Balçık, 2007). In the study that was done in Istanbul, it was revealed that vocational high school's organizational learning level was much better than general high school's level (Biber, Şişman, \& Gülseçen, 2011). The features of individual learning, team learning, and organizational learning have been demonstrated comparatively in the Table 1 (Demirel, 2008). 
Table 1

Comparison of Learning Levels

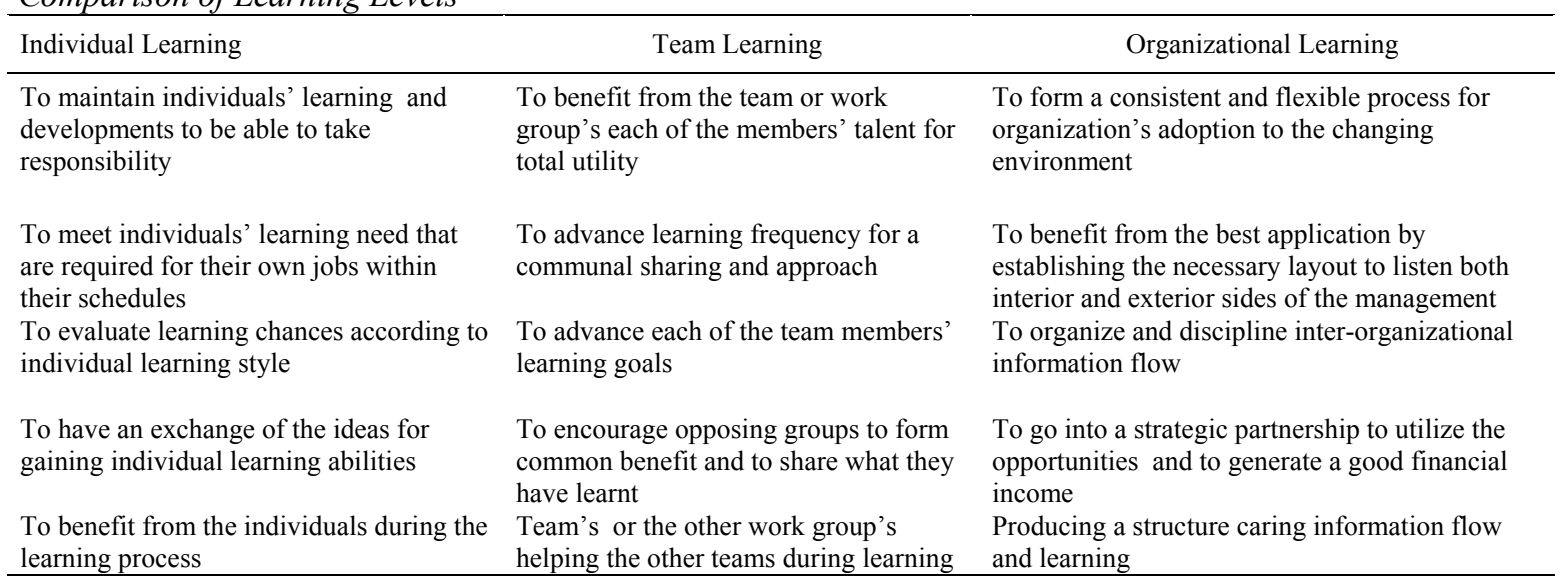

Learning in Community Level (Industrial Learning): Inter-organizational learning is a learning which emerges as a result of communal effort of the organizations that are dependent on each other with formal sectoral integration like alliances and networks. This type of learning has entered into the other learning levels in recent years. Industrial learning has been dealt as a broader concept than inter-organizational learning in literature (Karaöz, 2003).

Just as individuals, if organizations are in the learning process both singly and together, the industrials may also be in the same learning process. Industrial learning is a learning that occurs through the organization's being active in a certain sector sharing formal or informal environment and situations. Industrial learning consists of procedures like personnel's interorganizational transfer, the transfer of technology, communication, meeting, participating in fairs and conferences, courses and education, and examining the other organizations' products by dismantling and breaking into parts.

\section{Organizational Learning in Educational Institution}

Important developments have occurred in the function that educational institutions have undertaken from past to present. Besides the perception of teaching, the institutions should also adopt the perception of learning to be able to keep pace with developments happening fast (Kösterelioğlu \& Kösterelioğlu, 2008). Educational institutions should not be dealt only as institutions educating the students; they should be dealt as dynamic intuitions that reissue by changing and regenerating in time (Banoğlu, 2009). Educational institutions have to give importance to organizational learning more than the other managements. Because main mission of the educational institutions is to provide educational service, organizational learning has to be a part of the educational institutions' culture (Çelik, 2002).

Learning occurs in an environment in which certain opportunities and circumstances are supplied. The elements of the work environment are business application that encourages learning, team work that can cooperate, tolerating the mistakes while applying new data and abilities, allocating time for learning within hour of work, esteeming the status of the workers, reward systems encouraging innovativeness and learning, the existence of information technologies that will ease systematic feedback and information exchange (Çırpan, 2001). To realise organizational learning in educational institutions, teachers' participation in the 
decisions and in the applications should be provided; directors should support new ideas of the teachers and the students, their new projects, and their wish of new applications (Memduhoğlu \& Kuşçi, 2012).

\section{The Sample and the Subject Matter of the Research}

The subject matter of the research has covered science high school and Anatolian high school which are found in the city centre of Denizli, one of the most successful cities of Turkey in educational field. The research consists of 916 persons consisting of 621 managers and teachers working in public educational institutions and 295 managers and teachers working in private educational institutions. The stratified sampling technique was used in determining the research's sample. According to this technique, by taking into consideration a certain variant, the matter that the features existing in the subject matter related with this variant are also represented in the sample evenly is grounded (Altunışı, Coşkun, Bayraktaroğlu, \& Yıldırım, 2012). In the subject matter consisting of 916 persons, the average of the public educational institutions is $68 \%$ and the average of the private educational institutions is $32 \%$. Thereby, by choosing 359 persons from the public educational institutions and 169 persons from the private educational institutions, totally, 528 people were determined.

The pilot test of the questionnaire used in the research was applied in a private educational institution in Denizli. Fifty questionnaires were handed down and the administration of the questionnaire resulted in 46 usable returns. Participants found the items in the questionnaire comprehensible in general and they suggested that some of the words should be adapted according to the educational institutions.

\section{Research Hypotheses}

Learning is an essential subject for the organizations to be able to sustain their existence. Just as, if there are not individuals, there will not be organizations; organizational learning would not occur if the individuals forming the organizations have not learnt (Say1lır, 2001). For organizational learning, primarily, individuals need to learn. Afterwards, teams in which what is learnt at individual level and can be shared should be formed. For the success of the organizational learning, a learning system should follow the steps of the individual, team, organization, and community (Avc1 et al., 2010).

In sum, the following hypotheses were formulated:

$\mathbf{H}_{1}$ : There is a positive correlation between the individual learning and the team learning.

$\mathbf{H}_{2}$ : There is a positive correlation between the individual learning and the organizational learning.

$\mathbf{H}_{3}$ : There is a positive correlation between the individual learning and the community learning.

$\mathbf{H}_{4}$ : There is a positive correlation between the team learning and the organizational learning.

$\mathbf{H}_{5}$ : There is appositive correlation between the team learning and the community learning.

$\mathbf{H}_{6}$ : There is a positive correlation between the organizational learning and the community learning.

In educational institutions to determine the relations between the learning levels, correlation analysis has been used. In the studied literature, differences are expected in all levels of the organizational learning in private and public educational institutions due to some reasons; the 
private educational institutions think commercially makes them more dynamic and more open to learning than public institutions (Y1ldiz, 2011). Turkish bureaucratic system affects the public educational institutions (Gökçe \& Şahin, 2002); the fact that bureaucratic rules are prioritised in the public educational institutions and executive texts are often used in management may cause the students suppress the features of entrepreneurship and productiveness (Küçükoğlu, 2005). In private educational institutions in choosing human resources and in their promotion, applications based on competence and efficiency are allowed; in addition to this, preferring human resources open to learning inclined to team work and who can offer new solutions to serious problems and participating concept of management which is not centralist. Therefore between public educational institutions and private educational institutions:

$\mathbf{H}_{7}$ : There is difference in terms of individual learning levels.

$\mathbf{H}_{\mathbf{8}}$ : There is difference in terms of team learning.

$\mathbf{H}_{9}$ : There is difference in terms of organizational learning.

$\mathbf{H}_{\mathbf{1 0}}$ : There is difference in terms of community learning level.

In an attempt to analyze differences among the organizational learning levels of private and public educational institutions, the technique of Independent Samples T-test has been used.

\section{Method}

In the current research, the data were gathered by using questionnaire method. The questionnaire is composed of two chapters. These are general data belonging to participants and organizational learning level scale (Aydın \& Güçlü, 2012; Marsick \& Watkins, 1999). In the research, five point likert type statements were used.

The alpha coefficient was used to taste the reliability of the scale used in the research. Scales' value of Cronbach's alpha $(\alpha)$ is given in Table 2 and it can be said that the scales are reliable.

Table 2

Scales' Value of Cronbach's Alpha

\begin{tabular}{llc}
\hline & & Scales' Value of $\alpha$ \\
\hline 1. & Individual Learning & 0.863 \\
2. & Team Learning & 0.768 \\
3. & Organizational Learning & 0.961 \\
4. & Community Learning & 0.906 \\
\hline$* * * \mathrm{p}<.005$ &
\end{tabular}

Reliability is the degree of a test measuring the thing wanted to be measured (Altunış1k et al., 2012). Content validity and construct validity of the scales in the research was analyzed. In the content validity of Organizational Learning Scale that took part in the research, for the matters being able to be applied in educational institutions, some words and expressions were adopted and they were examined and reviewed by the academicians and practitioners' view. In addition, the preliminary test was also taken into consideration and the scale was put into final form.

To measure scales' construct validity, factor analysis was done by the method of Varimax Rotation. In determining whether the data acquired is suitable for the factor dissolving or not, 
Kaiser-Meyer-Olkin (KMO) and Barlett Tests were put into practice. As a consequence of factor analysis, the scale's Kaiser-Meyer-Olkin Measure of Sampling Adequacy resulted in 0.96. The fact that the value of KMO test is bigger than 0.5 , indicated that data set is suitable for factor analysis. The significance value of the Barlett Test was meaningful and showed that the correlation between the variants is meaningful. Moreover, the value of significance of the Scale's Barlett Test $\left(p=0.000 / \chi^{2}=31508.889 ; p<0.01\right)$ was meaningful.

\section{Results and Discussion}

The participants who participated in the questionnaire were 354 persons consisting of 328 teachers and 26 school managers who answered the questionnaire in total. In private educational institutions, 159 persons consisting of 139 teachers and 20 school managers answered the questionnaire in total. In private educational institutions, the average period of work of the persons having participated in the questionnaire is 3.8 years. Even though this period in private educational institutions seems lower than the average of the public educational institutions, it should be evaluated taking into account the private educational schools' period of set up and development in Denizli.

Regarding the analysis of the relationship among the organizational learning levels in educational institutions, in an attempt to determine whether there is relation among organizational learning levels or not, data acquired in the research was subjected to correlation analysis. When looked at the results of the correlation analysis in Table 3, it has been considered that the relation among the organizational learning levels is positively meaningful. So, $\mathrm{H}_{1}$ (r: 0.8151), $\mathrm{H}_{2}$ (r: 0.7711), $\mathrm{H}_{3}$ (r: 0.6474), $\mathrm{H}_{4}$ (r: 0.8058), $\mathrm{H}_{5}$ (r: 0.6606), and $\mathrm{H}_{6}$ (r: $0.7654)$ were accepted. According to this, it has been discovered that in educational institutions as far as the learning in low-level increases, learning in high levels increases as well. For organizational learning to happen, it requires bridges to be built that will ensure switching from individual level to team level, from team level to organizational learning level. These bridges here are possible by developing the components of communication, cooperation, transparency, rewarding, and integration simultaneously (Yazıc1, 2001).

Table 3 shows the correlation matrix among the organizational learning levels in educational institutions.

Table 3

Correlation Matrix among the Organizational Learning Levels in Educational Institutions

\begin{tabular}{lcccc}
\hline & Individual Learning & Team Learning & $\begin{array}{c}\text { Organizational } \\
\text { Learning }\end{array}$ & Community Learning \\
\hline Individual Learning & 1 & & & \\
Team Learning & $0.8151^{* * *}$ & 1 & 1 & 1 \\
Organizational Learning & $0.7711^{* * *}$ & $0.8058^{* * *}$ & $0.7654^{* * *}$ & 1 \\
Community Learning & $0.6474^{* * *}$ & $0.6606^{* * *}$ & \\
\hline
\end{tabular}

Organizational Learning Levels' Comparison in Public and Private Institutions: Data acquired was put to t-test in an attempt to evaluate whether public and private educational institutions act differently in those institutions considering the variants differently or not. When looked at the results of t-test in Table 4, it was concluded that there was a meaningful statistical 
difference between the public and private educational institutions. Table 4 presents the independent samples' test results.

Table 4

Independent Samples' Test Results

\begin{tabular}{lccccc}
\hline & \multicolumn{2}{c}{ Levene's Test for Equality of Variances } & \multicolumn{2}{c}{ t-test for Equality of Means } \\
\cline { 2 - 6 } Variances & $\mathrm{F}$ & $\mathrm{T}$ & $\mathrm{Sig}$. (2-tailed) & Mean Difference & $\begin{array}{c}\text { Standard Deviation } \\
\text { Difference }\end{array}$ \\
\hline Individual Learning & 42.558 & -9.55 & $0.000(* * *)$ & -0.64139 & 0.06716 \\
Team Learning & 17.686 & -8.958 & $0.000(* *)$ & -0.73388 & 0.08192 \\
Organizational Learning & 22.684 & -10.064 & $0.000(* *)$ & -0.68776 & 0.06834 \\
Community Learning & 39.249 & -8.863 & $0.000(* * *)$ & -0.62173 & 0.07015 \\
\hline
\end{tabular}

***: $p<0.001$

Teachers and managers working in public and private educational institutions' average values for each of the variances are seen in Table 5. Differences were found among all of the organizational learning levels in public and private educational institutions. In this case, $\mathrm{H}_{7}$, $\mathrm{H}_{8}, \mathrm{H}_{9}, \mathrm{H}_{10}$ hypothesis were accepted.

Table 5

The Average of Participants Answers According to Status of the Institutions

\begin{tabular}{llcccc}
\hline Variances & \multicolumn{1}{c}{ School's Status } & Number & Mean & SD & Standard Error \\
\hline \multirow{2}{*}{ Individual Learning } & Public Educational Institutions & 354 & 3.3785 & .77709 & .04130 \\
& Private Educational Institutions & 159 & 4.0199 & .50118 & .03975 \\
\multirow{2}{*}{ Team Learning } & Public Educational Institutions & 354 & 3.2881 & .91665 & .04872 \\
& Private Educational Institutions & 159 & 4.0220 & .71011 & .05632 \\
Organizational & Public Educational Institutions & 354 & 3.5127 & .78307 & .04162 \\
Learning & Private Educational Institutions & 159 & 4.2005 & .53581 & .04249 \\
Community Learning & Public Educational Institutions & 354 & 3.5157 & .81667 & .04341 \\
& Private Educational Institutions & 159 & 4.1375 & .50620 & .04014 \\
\hline
\end{tabular}

Having evaluated the means of the answers to individual learning matters of the participants of the research, it has been considered that individual learning in private educational institutions is above medium level with the average of $(\bar{x}=4.01)$ while in public educational institutions it is at medium level with the average of $(\bar{x}=3.37)$. This result has resembled the result of the survey in public and private primary education institutions in Istanbul (Aydin \& Güçlü, 2012). In individuals learning ability, their age and former learning are effective. Learning ability increases until young adulthood, then for a while, it remains stable and in middle and advanced ages, it shows decrease for a while. Knowledge and experience learnt formerly can act the role of helper or shackler in compliance with the similarity between the simulator and the behaviours (Şimşek et al., 1998). The informal relations in institutions that are strong will encourage organizational learning and discussions in teachers' room, and some cultural activities the institution organize should be aimed at supporting learning institution culture (Çelik, 2002).

When evaluated the averages of the answers given to the matters of team learning level, it can be evaluated that team learning level in private educational is above medium level with the 
average of $(\bar{x}=4.02)$; in public educational institutions, it is at medium level with the average of $(\bar{x}=3.28)$. In fact, in both of the educational institutions team learning level is not at a high level. This result showed similarity with the team learning level results of the research done in public primary institutions (Uysal, 2008). Uysal declares that even though regulations, in which it is supposed that individual learning is rewarded, are few in existence, the lack of legal regulations towards rewarding team learning and team success have a negative effect on development of team learning level.

According to the average of the answers given about the organizational level of learning, it was determined that in private educational institutions organizational learning level is above medium level with the average of $(\bar{x}=4.20)$, in public educational institutions it is at medium level with the average of $(\bar{x}=3.51)$.

This situation is in private educational schools' favour in a similar way with the result of Aydın \& Güçlü (2012) research. In a research about organizational learning in public educational institutions, it was determined that perception level of the teachers in Anatolian and Science High School is higher than the teachers' level in Vocational and Technical High School (Çandır, 2012). It has been indicated that knowledge management is instrumental in organizational learning's coming out. Knowledge management in educational institutions is the management of the periods that are knowledge acquisition depending on the knowledge obtained from internal and external resources and on the experience the teachers own, spread of the knowledge, interpretation and explanation of the data, information storage, and reexamination of the information (Üzüm, 2009).

When evaluated participants' answers to the community learning, it has been considered that in private educational institutions community learning is above medium level with the average of $(\bar{x}=4.13)$; in public educational institutions it is at medium level with the average of $(\bar{x}=3.51)$. In another research done in this field, private educational institutions' average of community learning has taken place at a higher level than the public educational institutions' community learning (Aydın \& Güçlü, 2012).

\section{Conclusion}

In an attempt to evaluate whether there is a relation among organizational learning levels in educational institutions, data acquired from the research was subjected to correlation analysis and it was established that there is positively meaningful relations among the learning levels. It was determined that there is a positive relation between the individual learning and team learning (Avcı \& Küçükusta, 2009; Demirel, 2008). Because learning starts with the individual, students should be supported and encouraged to learn. With this purpose, rewards can be given; their participation in the courses, seminars, and conferences can be supported in terms of time and money. In the researches done, it was determined that team learning occurs at a lower level than the individual learning. The fact that students cannot come together and there is not integration between each other prevents knowledge being transferred from individual learning to team learning (Avc1 et al., 2010; Erigüç \& Balçık, 2007). In another study, it was stated that team learning is performed in schools but this is not adequate for team learning. It emerged that 
teachers and managers wanted to participate in the group work, they enjoyed this and they are inclined to doing this but there are shortages in enabling environments in which team work can be done in schools and there are also shortages in doing the works through team work (Memduhoğlu \& Kuşçi, 2012).

Organizational learning is based on learning of the individuals working in organizations. It has been considered that there is positively strong relation between individual learning and organizational learning. As the level of organizational learning increases, the level of individual learning also increases in the same direction (Avc1 \& Küçükusta, 2009; Demirel, 2008). When examined the organizational level of the field study done in primary schools, the expression "management, change and open to changes" has the highest average while the expression "personnel is subject to a continuous education related with development and change" has the lowest average (Menteşe, 2013). In another research private school managers are at a higher level than primary school managers in activities enabling organizational learning (Aydın \& Güçlü, 2012).

Team learning in organizations functions as a bridge in transferring knowledge at individual level into organizational level. In the research done, it was determined that there is a positive relation at medium level between the team learning and organizational learning (Avc1 \& Küçükusta, 2009; Demirel, 2008). Although there are regulations which are supposed that individual learning rewards, there are no legal regulations towards rewarding team learning and team success. It is thought that this situation affects negatively team learning developments in primary schools (Uysal, 2008). It was confirmed that teachers performing in private schools give more importance to team learning and cooperation than the teachers in public schools (Aydın \& Güçlü, 2012). In a research done about organizational learning in primary schools, it was revealed that teachers and managers sometimes actualise organizational learning at a medium level (Memduhoğlu \& Kuşçi, 2012).

These are the results acquired from the analysis of the research aiming at analyzing levels of organizational learning in educational institutions and whether there is a difference between the institutions or not:

It was aimed at analyzing whether there is a difference in organizational learning between the public and private educational institutions or not. According to the results of the t-test done, it was referred that there is a meaningful difference between the educational institutions. When at the averages of the variances of organizational learning the participants gave as an example were taken into consideration, it was determined that in all levels private educational institutions are relatively high in favour of them. This result shows resemblance with the result of the research Yildiz (2011) did in Balikesir. According to Y1ldiz, in fact this result is an expected situation; the fact that private educational institutions think commercially have made them more dynamic and more open to learning than public institutions.

It has been considered that finding the results of organizational learning in private institutions has come out because of preferring human resources open to learning, apt to team learning, being able to find new solutions for the serious problems, and as a result of a participating management concept which is not centralist. The fact that in educational institutions bureaucratic rules are prioritized and in management executive tests are often applied will be able to cause teachers and managers suppress their feature of entrepreneurship 
and innovativeness related with education (Küçükoğlu, 2005). Public's expectation of service quality in public schools has increased; public institutions should increase their service quality through taking lessons from their former experiences and that they should maximize social benefit.

Learning in all levels in educational institutions that educate human labouringly in a long period of time should be high. For organizational learning to occur in all levels, it is believed that forming a public culture providing an environment for permanently learning in the structure of the institutions is useful. For organizational learning level to be high in educational institutions, it is thought that managers should support their workers' new ideas, projects, and their wishes of new applications. Workers in institutions will be able to improve both themselves and their work by permanently learning and putting into practice what they have learnt into what they are doing. However, during the period of research it was seen that there was a lack of "systematically problem solving". The activity of systematically problem solving in institutions are approached as the activities based on scientific method rather than problem identification and estimation, related with the subject decision taking into consideration data rather than hypothesis and involving usage of the statistical means in gathering up the data (Özgen \& Türk, 1996).

For raising the organizational level of learning's results, improvements in teachers' and managers' level of knowledge and their experience should be evaluated and be disseminated overall the institutions. Sectoral learning among the institutions arises from methods like transfer of the workers among institutions, mutual communication among institutions, participating in the meetings, fairs and conferences, analysis of other institutions' period of learning, and projects. Innovations revealed out by any of the educational institution active in education sector will be learnt by the other institutions in the sector. However, because of the rivalry within private educational institutions, it is thought that learning pace and data's dissemination period within educational institutions will change according to the wish of keeping knowledge and practice as a secret.

Provincial and district national education directorates can take supplying learning within educational institutions and private and public educational institutions coming together on a coordinating task. In the period of research, applications supporting learning within the institutions are encountered more in private educational institutions like chain in different provinces. It is thought that primarily public and private educational institutions should first come together between each other, then they should come together with different means in different environments and they should share their experience and knowledge and produce mutual educational projects in favour of Denizli's educational sector.

These are the suggestions made for the researchers who want to make a research in the subjects of organizational learning: With the aim of adapting to the changes and innovations for managers and teachers in educational institutions, qualitative researches revealing to what extent they are open to learning and development can be done. As a part of the mass culture, researches can be done about the subjects how organizational learning can occur in the educational institutions in Turkey and how educational institutions can be a learning organization. Community learning dealt with as the fourth level of organizational learning can make a research securing literature uniformity by evaluating different concepts like sectoral 
learning and inter-organizational learning. In the future research, the components of the organizational learning can systematize factors developing and restraining as a knowledge. For sectoral learning to happen within the organizations, a study can be done to know how the rivalry among the private educational institutions will be harmonised and how the coordination will be provided in private educational institutions coming together.

\section{References}

Altunışık, R., Coşkun, R., Bayraktaroğlu, S., \& Yıldırım, E. (2012). Sosyal bilimlerde araştırma yöntemleri. Sakarya: Sakarya Kitapevi.

Argyris, C., \& Schön, D. A. (1996). Organizational learning II: Theory, method, and practice. Reading, MA: AddisonWesley Publication Company.

Avcı, N., \& Küçükusta, D. (2009). Konaklama işletmelerinde örgütsel öğrenme, örgütsel bağl1lık ve işten ayrılma eğilimi arasındaki ilişki. Anatolia: Turizm Araştırmaları Dergisi, 20(1), 33-44.

Avc1, U., Kılınç, İ., \& Okumuş, F. (2010). Öğrenme düzeyleri arası ilişki: Otel işletmelerinde bir alan araştırması. Ege Academic Review, 10(1), 95-115.

Aydın, M. K., \& Güçlü, N. (2012). Kamu ve özel ilköğretim okulu müdürlerinin stratejik liderlik özellikleri ile kurumlarının örgütsel ögrrenme düzeyleri arasındaki ilişki (Unpublished master's thesis), Gazi Üniversitesi, Ankara.

Aydoğan, E., Orhan, F., Naldöken, Ü., Beylik, U., \& Aksay, K. (2011). Sağlık kurumlarında örgütsel öğrenme kapasitesi: Bir kamu hastanesi örneği. Cumhuriyet Üniversitesi İktisadi ve İdari Bilimler Dergisi, 12(2), 191-213.

Aytaç T. (2000). Eğitimde yönetiminde yeni paradigmalar, okul merkezli yönetim. Ankara: Nobel Yayın Dağıtım.

Bacanlı, H. (2002). Gelişim ve öğrenme. Ankara: Nobel Yayın Dağıtım.

Banoğlu, K. (2009). Okullarında görev yapmakta olan yönetici ve ögrretmenlerin ögrrenen örgüt algısı (Unpublished master's thesis). Yıldız Teknik Üniversitesi, İstanbul.

Biber, K. S., Şişman, B., \& Gülseçen, S. (2011). Genel liseler ve meslek liselerinin örgütsel öğrenme düzeyleri bakımından karşılaştırılması. Eğitim Bilimleri ve Uygulama Dergisi, 10(20), 197-217.

Çandır, R. (2010). Lise ögretmenlerinin örgütsel öğrenme düzeyine ilişkin algıları (Unpublished master’s thesis). Pamukkale Üniversitesi, Denizli.

Çelik, V. (2002). Okul kültürü ve yönetimi. Ankara: Pegem Akademi.

Çırpan, H. (2001). Bilgi işçilerini şirkette tutmanın bir yolu: Öğrenme ortamı. Active, 1, 1-15.

Demirel Y. (2008). Örgütsel öğrenme kültürü ve iş tatminin öğrenme motivasyonu üzerine etkisi: Otomotiv sektöründe ampirik bir çalışma. Akademik Bakış Uluslararası Hakemli Sosyal Bilimler Dergisi, 1(14), 1-22.

Doğan, K. (2010). Örgütsel ögrrenme ve kriz yönetimi arasındaki ilişkilerin incelenmesi (Unpublished master's thesis), Kadir Has Üniversitesi, İstanbul.

Erçetin, Ş. Ş. (2001). Örgütsel zekâ. Ankara: Nobel Yayın Dağıtım.

Erigüç, G., \& Balçık, P. Y. (2007). Öğrenen örgüt ve hemşirelerin değerlendirmelerine yönelik bir uygulama. Hacettepe Sağllk İdaresi Dergisi, 10(1), 75-106.

Gökçe, O., \& Şahin, A. (2002). 21. Yüzyılda Türk bürokrasisinin sorunları ve çözüm önerileri. Selçuk Üniversitesi İIBF Sosyal ve Ekonomi Araştırmalar Dergisi, 3, 1-27.

İnce, M., Bedük, A., \& Aydoğan, E. (2004). Örgütlerde takım çalışmasına yönelik etkin liderlik nitelikleri. Selçuk Üniversitesi Sosyal Bilimler Enstitüsü Dergisi, 11, 423-446.

Karadağ, N. (2002). Öğrenen organizasyonlar ve örgütsel öğrenme yetersizliklerine ilişskin bir inceleme (Unpublished master's thesis), Gebze İleri Teknoloji Enstitüsü, Gebze.

Karaöz, M. (2003). Öğrenme ve farklı talep fonksiyonlarını içeren ekonomik üretim miktarı model önerileri (Unpublished doctoral dissertation). Süleyman Demirel Üniversitesi, Isparta.

Koç, U. (2009). Örgütsel öğrenme: Tanımı, yakın terimler arasındaki kavramsal ayrımlar ve davranışsal yaklaşım. Afyon Kocatepe Üniversitesi İktisadi ve İdari Bilimler Fakültesi Dergisi, 11(1), 151-165.

Kösterelioğlu, İ., \& Kösterelioğlu, M. A. (2008). Okul temelli mesleki gelişim çalışmalarının, okullarda öğrenen örgüt kültürü oluşturmaya katkısı. Sakarya Üniversitesi Fen Edebiyat Dergisi, 10(2), 243-255. 
Küçükoğlu, A. (2005). Örgütsel öğrenme ve öğrenmenin engelleri. Milli Eğitim ve Sosyal Bilimler Dergisi, 166, Retrieved from http://dhgm.meb.gov.tr/yayimlar/dergiler/Milli_Egitim_Dergisi// 166/index3-kucukoglu.htm.

Lucas, L. M. (1999). The development of integrated approach to organizational learning. Paper presented at the third International Conference on Organizational Learning, Lancaster University, United Kingdom.

Marsick, V. J., \& Watkins, K. E. (1999). Facilitating learning organizations: Making learning count. Aldershot and Brookfield: Ashgate Publishing Co.

Menteşe, S. (2013). İlköğretim öğretmenlerinin öğrenen örgüte ilişkin görüşleri. The Journal of Academic Social Science Studies, 6(3), 451-478.

Memduhoğlu, H. B., \& Kuşçi, E. (2012). Yönetici ve öğretmenlerin algılarına göre ilköğretim okullarında örgütsel öğrenme. İlkögretim Online, 11(3), 748-761.

Mirzaei Daryani, S., Sattari Ardabili, F., \& Amini, M. (2014). The study models of learning organization building. International Journal of Learning and Intellectual Capital, 11(4), 320-333.

Morris, C. G. (2002). Psikolojiyi anlamak: Psikolojiye Giriş. Ankara: Türk Psikologlar Derneği Yayınları.

Nikooravesh, A., Parpoochi, A., \& Mohammad Davoudi, A. H. (2016). The impact of team-based learning on knowledge development. International Journal of Organizational leadership, 5(2), 110-122.

Öncül, M. S. (1999). Örgütsel öğrenme. MPM Verimlilik Dergisi, 2, 7-24.

Özgen, H., \& Türk, M. (1996). Öğrenen örgüt sistemi ve bir öğrenen örgüt modeli. Amme İdaresi Dergisi, 29(2), 71-85.

Sayılır, A. (2001). Bireysel Öğrenme ile örgütsel öğrenme arasındaki bağ. İstanbul Üniversitesi Siyasal Bilgiler Fakültesi Dergisi, 25, 229-243.

Şahinkesen, Ö. G. (2010). Öğrenen organizasyonlar: Gaziosmanpaşa Üniversitesi’nde bir uygulama (Unpublished master's thesis). Gaziosmanpaşa Üniversitesi, Tokat.

Şimşek, Ş., Akemici, T., \& Çelik, A. (1998). Davranış bilimlerine giriş ve örgütsel davranış. Ankara: Nobel Yayın Dağıtım.

Uysal, R. (2008). İlköğretim okulu ögretmenlerinin örgütsel ögrrenme algllarl (Unpublished master's thesis). Yeditepe Üniversitesi, İstanbul.

Üzüm, S. (2009). Resmi ilköğretim okullarında örgütsel öğrenme aracı olarak bilgi yönetimi. (Unpublished master's thesis). Beykent Üniversitesi, İstanbul.

Vera, D., \& Crossan, M. (2004). Strategic leadership and organizational learning. Academy of Management Review, 29(2), 222-240.

Yazıcı, S. (2001). Öğrenen Organizasyonlar. İstanbul: Alfa Basım Yayım.

Yıldırım E. (2006). Örgütsel öğrenmenin öncülü olarak örgütsel zekâ: Teori ve bir uygulama. Selçuk Üniversitesi, İktisadi ve İdari Bilimler Fakültesi, Sosyal ve Ekonomik Araştırmalar Dergisi, 14(20), 145-170.

Yıldız, H. (2011). Kamu ve özel ilköğretim kurumlarında çalışan öğretmenlerin öğrenen örgüte ilişkin algıları: Balıkesir ili örneği (Unpublished master's thesis). Balıkesir Üniversitesi, Balıkesir.

Zehir, C., \& Özşahin, M. (2008). Takım yönetimi ve takım etkinliğini belirleyen faktörler: Savunma sanayinde Ar-ge yapan takımlar üzerinde bir saha araştırması. Doğuş Üniversitesi Dergisi, 9(2), 266-279. 